\title{
Using satellite-based estimates of evapotranspiration and groundwater changes to determine anthropogenic water fluxes in land surface models
}

\author{
R. G. Anderson ${ }^{1, *}$, M.-H. Lo ${ }^{2, *}$, S. Swenson ${ }^{3}$, J. S. Famiglietti ${ }^{4}$, Q. Tang ${ }^{5}$, T. H. Skaggs ${ }^{1}$, Y.-H. Lin ${ }^{2}$, and R.-J. Wu ${ }^{3}$ \\ ${ }^{1}$ USDA, Agricultural Research Service, US Salinity Laboratory, Contaminant Fate and Transport Unit, \\ Riverside, CA, USA \\ ${ }^{2}$ National Taiwan University, Department of Atmospheric Sciences, Taipei, Taiwan \\ ${ }^{3}$ National Center for Atmospheric Research, Advanced Study Program, Boulder, CO, USA \\ ${ }^{4}$ Jet Propulsion Laboratory, California Institute of Technology, 4800 Oak Grove Dr., Pasadena, CA 91109, USA \\ ${ }^{5}$ Key Laboratory of Water Cycle and Related Land Surface Processes, Institute of Geographic Sciences and Natural \\ Resources Research, Chinese Academy of Sciences, Beijing, China \\ *These authors contributed equally to this work.
}

Correspondence to: R. G. Anderson (ray.anderson@ars.usda.gov) and M.-H. Lo (minhuilo@ntu.edu.tw)

Received: 6 February 2015 - Published in Geosci. Model Dev. Discuss.: 29 April 2015

Revised: 4 September 2015 - Accepted: 14 September 2015 - Published: 2 October 2015

\begin{abstract}
Irrigation is a widely used water management practice that is often poorly parameterized in land surface and climate models. Previous studies have addressed this issue via use of irrigation area, applied water inventory data, or soil moisture content. These approaches have a variety of drawbacks including data latency, accurately prescribing irrigation intensity, and a lack of conservation of water volume for models using a prescribed soil moisture approach. In this study, we parameterize irrigation fluxes using satellite observations of evapotranspiration (ET) compared to ET from a suite of land surface models without irrigation. We then incorporate the irrigation flux into the Community Land Model (CLM) and use a systematic trial-and-error procedure to determine the ground- and surface-water withdrawals that are necessary to balance the new irrigation flux. The resulting CLM simulation with irrigation produces ET that matches the magnitude and seasonality of observed satellite ET well, with a mean difference of $6.3 \mathrm{~mm} \mathrm{month}^{-1}$ and a correlation of 0.95. Differences between the new CLM ET values and satellite-observed ET values are always less than $30 \mathrm{~mm} \mathrm{month}^{-1}$ and the differences show no pattern with respect to seasonality. The results reinforce the importance of accurately parameterizing anthropogenic hydrologic fluxes into land surface and climate models to assess environmental
\end{abstract}

change under current and future climates and land management regimes.

\section{Introduction}

Agricultural irrigation is the dominant anthropogenic use of surface water and groundwater globally (Postel et al., 1996; Siebert et al., 2010; Wisser et al., 2008). Irrigation, and its associated movement, storage, and depletion of surface and ground waters, can induce major changes in regional hydrology (Ferguson and Maxwell, 2012; Haddeland et al., 2006; Tang et al., 2008) and climatology (Kueppers et al., 2007; Lo and Famiglietti, 2013). Irrigation demand has resulted in groundwater depletion across multiple regions of the world (Famiglietti, 2014), including the western United States (Famiglietti et al., 2011; Scanlon et al., 2012), the Middle East (Voss et al., 2013), and India (Rodell et al., 2009). Globally, this depletion has a net effect on continental runoff and sea level rise (Van Djik et al., 2014; Wada et al., 2010). Given the impact of irrigation on hydrology, climate, and food production, it is crucial to be able to accurately model irrigation in current land surface models (e.g., Rodell et al., 2004; Xia et al., 2012a) in order to assess poten- 
tial land-atmosphere feedback mechanisms that may impact future water availability for irrigation, municipal, and environmental uses.

Current land surface models (LSMs), such as the Community Land Model (CLM; Oleson et al., 2008), that are run without an irrigation parameterization usually have unrealistically low evapotranspiration in agricultural regions (Lei et al., 2015; Lo et al., 2013; Lobell et al., 2009; Sorooshian et al., 2011; Ozdogan, 2010). Given that irrigation is predominantly used in semi-arid to arid regions and/or regions where precipitation and growing seasons are asynchronous, this lack of parameterization can be highly significant for modeling regional hydrology. Some LSMs and their associated regional climate models (RCMs) or global climate models (GCMs) prescribe enhanced water availability in agricultural regions due to irrigation. Representations vary considerably depending on the simulation; they include (1) prescribing a static soil moisture at field capacity for all irrigated crops (Kueppers et al., 2007), (2) prescribing a total flux based on a prescribed estimate across the entire agricultural domain (Lo and Famiglietti, 2013), (3) assigning a fraction of land surface to be irrigated (Leng et al., 2013, 2014; Lobell et al., 2009; Tang et al., 2007), and (4) assigning a seasonally based soil moisture curve to represent irrigation only during the active irrigation season (Sooroshian et al., 2011). Each of these approaches has significant disadvantages. The approaches that assign irrigation based on soil moisture (approaches 1 and 4 above) do not consider basin-scale limitations on available irrigation water (particularly during dry years) and may overestimate the total amount of irrigation water as well as the differential impacts between dry and wet years. The prescribed/inventory-based flux (approach 2) has the advantage of a mostly conserved water budget, but there are latency issues for much of the data which are based on potentially outdated or incomplete national and regional statistics. Assigning a fraction of land area to be irrigated (approach 3) has the disadvantage of assuming a particular irrigation intensity, and this approach cannot easily distinguish between full and deficit irrigation. Finally, some prescribed flux approaches work primarily where groundwater is the sole source for applied irrigation, and others based on irrigated area may not account for irrigation intensity. While process differences in RCMs/GCMs and LSMs can account for variations in the sensitivity of irrigation-climate feedbacks and teleconnections, it should be noted that studies with different irrigation parameterizations over the same region have had significantly different climatic feedbacks and downwind impacts (Kueppers et al., 2007; Lo and Famiglietti, 2013; Lo et al., 2013; Sooroshian et al., 2011).

Satellite remote sensing can be used to provide more robust, regional observations of irrigation water consumption. Evapotranspiration (ET) is routinely monitored over irrigated agriculture using observations of surface temperature and vegetation greenness (Allen et al., 2007; Anderson et al., 2007; Tang et al., 2009a). The precision and accuracy of satellite ET algorithms, particularly those that incorporate land surface temperature data, is sufficiently high to quantify water management and water rights transfers (Cuenca et al., 2013; Steele et al. 2015; Tang et al., 2009b). When combined with satellite gravimetry (Swenson and Wahr, 2003) and large-scale meteorological products (Hart et al., 2009), the amount of irrigation water coming from surface water supplies (Anderson et al., 2012) and net groundwater depletion (Famiglietti et al., 2011) can be assessed. Together, these satellite algorithms can provide a much more detailed and current input data set for LSMs and RCMs/GCMs to assess irrigation-climate feedbacks.

In this study, we follow on the work of Lo and Famiglietti (2013) by using remote sensing observations of ET, surface water consumption, and total water storage anomalies to infer surface water and groundwater fluxes, instead of using a static surface water and groundwater irrigation inventory data set for parameterization. We use these fluxes to improve and test an irrigation parameterization in the Community Land Model (Lawrence et al., 2011; Oleson et al., 2008) in a well instrumented basin with a large amount of irrigated agriculture, the Central Valley of California. We use ET from an ensemble of three satellite products, combined with gridded precipitation, to determine the seasonality and interannual variability of additional ET from irrigation. We then use an iterative recharge parameterization, combined with satellite gravimetry, to determine relative amounts of irrigation applied from groundwater and surface water. The results show the ability and value of using diagnostic remote sensing observations and models for improving prognostic algorithms necessary to increase LSM skill in predicting hydrologic, biogeochemical, and climatic impacts and feedbacks under future greenhouse gas emission and land use change scenarios.

\section{Methods}

\subsection{Study region}

We evaluate our approach in the Central Valley of California, which is a large $\left(\sim 54000 \mathrm{~km}^{2}\right)$, low elevation $(<200 \mathrm{~m}$ a.s.l.) region (Fig. 1). The Central Valley is a highly productive agricultural region, with over 200 cultivated crops and an annual crop value of more than USD 35 billion in 2012 (California Department of Food and Agriculture, 2014; USDA National Agricultural Statistics Service, 2014). Relevant aspects of the Central Valley's geology (Planert and Williams, 1995; Faunt, 2009), climatology (Zhong et al., 2004), hydrology (Scanlon et al., 2012), and anthropogenic interbasin water transfers (Chung and Helweg, 1985; Fischhendler and Zilberman, 2005) are extensively reviewed elsewhere. Average (2004-2009 water years) blue water (surface water plus groundwater) consumption was $2.03 \pm 0.02$ $\mathrm{X} 10^{10} \mathrm{~m}^{3}$ as determined using an inventory method (Ander- 
son et al., 2012). Agriculture in the Central Valley is heavily dependent upon irrigation from both surface water and groundwater, with a large variation in the relative consumption of surface water and groundwater due to high interannual variation in precipitation and an almost complete lack of precipitation during the peak summer growing season (Anderson et al., 2012; Scanlon et al. 2012). In particular, many farmers have both surface- and groundwater irrigation infrastructure and will pump more groundwater when surface water deliveries are insufficient. In addition to its agricultural importance, the Central Valley has multiple attributes that are useful for developing and validating new model processes to better represent anthropogenic impacts on regional hydrology and climatology. These include (a) well-understood hydrogeology, surface water use, and extensive in situ meteorological observations (Hart et al., 2009; Faunt, 2009; Planert and Williams, 1995); (b) well constrained groundwater systems with little to no subsurface outflow to the ocean (Faunt, 2009); (c) well-gauged and modeled surface water flows into and out of the valley (Anderson et al., 2012); and (d) anthropogenic hydrologic processes (irrigation, crop evapotranspiration, and drainage) that have a very distinct seasonality from the winter precipitation and spring-runoff-dominated natural processes that occurred prior to irrigation and agricultural development (Lo and Famiglietti, 2013).

Previous remote-sensing-based and mechanistic modeling studies have shown sustained and substantial depletion of groundwater in the Central Valley (Famiglietti et al., 2011; Faunt, 2009), which has accelerated in the most recent drought from 2012 to present (Borsa et al., 2014; Famiglietti, 2014). This reliance on remote sensing and modeling is due, in part, to the historically minimal well reporting requirements from the State of California, resulting in a relative paucity of publicly available groundwater extraction data. Recent groundwater regulation legislation will likely restrict future groundwater pumping differentially across groundwater basins (Harter and Dahlke, 2014), making alternative irrigation methods and strategies, such as drip and deficit irrigation, more common and potentially altering the amount and seasonality of irrigation. The potential for rapid hydrologic changes in the Central Valley (such as sudden restrictions on groundwater pumping or whole-scale conversions in irrigation method) is one reason why a potentially dynamic, satellite-based irrigation parameterization would be useful for land surface modeling.

\subsection{Evapotranspiration, precipitation and total water observations}

We calculated the monthly mean and standard deviation of evapotranspiration (ET) using an ensemble of three products. One is a surface energy balance product (Anderson et al., 2012) based on the SEBAL algorithm (Surface Energy Balance Algorithm for Land; Bastiaanssen et al., 1998) that is applied to the Central Valley at $250 \mathrm{~m}$ resolution using

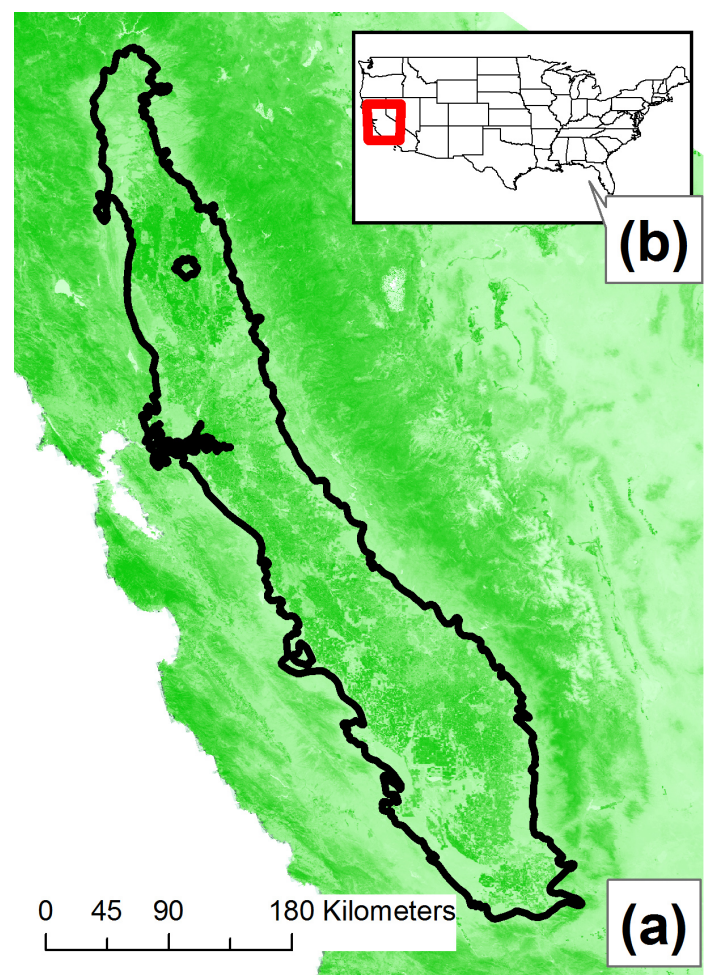

Figure 1. Map of the Central Valley, California. (a) Underlying normalized differential vegetation index (NDVI) from the MODerate resolution Imaging Spectroradiometer (MODIS) 250 m, 16-day product (July 2006) illustrating irrigated regions of the Central Valley (black outline). Darker green indicates higher NDVI and vegetation cover. (b) Map of the United States with the inset area of (a) outlined in red.

a $250 \mathrm{~m}$ vegetation index and $1 \mathrm{~km}$ thermal data from the MODerate resolution Imaging Spectroradiometer (MODIS) in conjunction with gridded meteorology. The second product (Tang et al., 2009a) uses the scatter plot relationship between the vegetation index and surface temperature (VI$\mathrm{Ts})$ to estimate the evaporative fraction (EF) and ET at $0.05^{\circ}$ resolution using MODIS vegetation and thermal data in conjunction with Geostationary Operational Environmental Satellite (GOES) surface radiation products. The third product (Jin et al., 2011), uses the Priestley-Taylor equation (Priestley and Taylor, 1972) with the coefficient term $(\alpha)$ optimized using AmeriFlux data and net radiation and ground heat flux parameterized from the MODIS and Clouds and the Earth's Radiant Energy System (CERES) instruments to estimate ET at $1 \mathrm{~km}$ resolution. All three products were clearly able to distinguish peak summertime ET in the Central Valley, which is asynchronous with largely winter precipitation and which is a characteristic sign of irrigation. Other ET products (e.g., Miralles et al., 2011; Mu et al., 2011; Jung et al., 2010) were not used as they were either too coarse in resolution $\left(>0.25^{\circ} \times 0.25^{\circ}\right.$ cell size $)$ or were unable to detect irrigation in the Central Valley. 
Monthly precipitation (approximately $4 \mathrm{~km}$ spatial resolution) was obtained using the Parameter-elevation Regressions on Independent Slopes Model (PRISM), which interpolates station precipitation data, accounting for orography (Daly et al., 1994, 2008). Observations of total water changes were obtained from the Gravity Recovery And Climate Experiment (GRACE) mission (Tapley et al., 2004) for the entire Sacramento and San Joaquin river basins (including the usually endoheric Tulare Lake basin). Using the methodology of Famiglietti et al. (2011), groundwater changes were obtained by removing snow, soil moisture, and surface reservoir storage variations from the total water storage anomalies from GRACE. Groundwater changes in the combined basins were assumed to have occurred entirely within the Central Valley where major agricultural and municipal wells exist rather than in the non-irrigated, sparsely populated, mountainous regions surrounding the valley.

\subsection{Land surface models}

For intercomparison with satellite-observed fluxes and determination of additional water application in CLM, we use an ensemble (nine members) of three North American Land Data Assimilation System outputs (NLDAS-2 - Mitchell et al., 2004; Xia et al., 2012b), four Global Land Data Assimilation System (GLDAS-1 - Rodell et al., 2004) outputs, and two CLM simulations. For NLDAS-2 and GLDAS-1, we used the Noah, Mosaic, VIC (Variable Infiltration Capacity), or CLM models from each system with the primary NLDAS2 and GLDAS- 1 forcings. Along with the NLDAS/GLDAS outputs, we also include outputs from different versions of the CLM (including CLM3.5 and CLM4) with the GLDAS-1 atmospheric forcings. Our intention with including this number of permutations of LSMs and LSM forcings was to increase our confidence in the mean and uncertainty of nonirrigated ET. In addition, we evaluated the CMIP5 control outputs (Taylor et al., 2012) to assess the larger performance of climate models in assessing latent heat fluxes across agricultural regions. Details about the CMIP5 models and simulations are provided in Supplement Sect. 1. For our study, CLM is run at $0.125^{\circ}$ by $0.125^{\circ}$ grid cells with $30 \mathrm{~min}$ temporal resolution.

The water budget for the soil layer and groundwater in CLM can be written as

$$
\begin{aligned}
& \Delta \mathrm{SM}=P-\mathrm{ET}-Q_{\mathrm{S}}-q_{\text {recharge }}, \\
& \Delta \mathrm{GW}=q_{\text {recharge }}-Q_{\mathrm{d}},
\end{aligned}
$$

where $\Delta \mathrm{SM}$ is soil moisture change, $P$ is precipitation, ET is evapotranspiration, $Q_{\mathrm{S}}$ is surface runoff, $q_{\text {recharge }}$ is groundwater recharge, $\Delta \mathrm{GW}$ is groundwater storage changes, and $Q_{\mathrm{d}}$ is groundwater discharge. However, Eqs. (1) and (2) only reflect the natural hydrology and neglect the substantial contribution of irrigation in major agricultural regions as previously discussed. A more reasonable equation should include the aforementioned irrigation water from surface (river) water $\left(\mathrm{SW}_{\mathrm{WD}}\right)$ and from groundwater withdrawal $\left(\mathrm{GW}_{\mathrm{WD}}\right)$ as shown in Fig. 2 and Eqs. (3) and (4). We will incorporate the estimated irrigation water use into the CLM version 4 and the withdrawn water in the irrigation process will be treated as an extra water input (effective precipitation).

$$
\begin{aligned}
& \Delta \mathrm{SM}=P-\mathrm{ET}-Q_{\mathrm{S}}-q_{\text {recharge }}+\mathrm{GW}_{\mathrm{WD}}+\mathrm{SW}_{\mathrm{WD}} \\
& \Delta \mathrm{GW}=q_{\text {recharge }}-Q_{\mathrm{d}}-\mathrm{GW}_{\mathrm{WD}}
\end{aligned}
$$

\subsection{CLM groundwater and surface water application parameterization}

We use the difference $(\Delta \mathrm{ET})$ between remote-sensingobserved ET $\left(\mathrm{ET}_{\mathrm{obs}}\right)$ and the original model-parameterized ET $\left(\mathrm{ET}_{\mathrm{om}}\right)$ to estimate total applied surface water and groundwater as shown in Eq. (5).

$\Delta \mathrm{ET}=\mathrm{ET}_{\mathrm{obs}}-\mathrm{ET}_{\mathrm{om}}=\mathrm{SW}_{\mathrm{WD}}+\mathrm{GW}_{\mathrm{WD}}$

$\triangle \mathrm{ET}$ in Eq. (5) is determined as an interannual (2004-2009) mean difference between satellite-observed and modeled ET. Water is applied evenly in CLM4 throughout the primary growing and irrigation season (May-October). We can partition the total withdrawn irrigation water into $\mathrm{SW}_{\mathrm{WD}}$ and $\mathrm{GW}_{\mathrm{WD}}$ by requiring that Eqs. (3) and (4) are both satisfied by the CLM4 simulation. A systematic, trial-and-error procedure is used to determine the necessary partitioning using groundwater recharge since it is a common variable to both equations. For each trial, a value of $q_{\text {recharge }}$ is guessed. $\mathrm{GW}_{\mathrm{WD}}$ is then determined from rearranging Eq. (4), with $\Delta \mathrm{GW}$ and $Q_{\mathrm{d}}$ being set to average values derived from processed GRACE $\triangle \mathrm{GW}$ and the baseline simulations for the study period (2004-2009), respectively. $\mathrm{SW}_{\mathrm{WD}}$ is then found as a residual from Eq. (5), and CLM4 is run. The model run generates a simulated recharge (Eq. 3). If the trial (or "parameterized") recharge value and the simulated recharge value agree, then Eqs. (3) and (4) are satisfied and the partitioning is accepted. Equation 5 notes that all abstracted water eventually contributes to ET. While this assumption may be violated at a field scale, it likely holds at a regional scale in the Central Valley where extensive conjunctive use and reuse of water occurs (Canessa et al., 2011).

To find the correct recharge and withdrawal partitioning, we ran a series of trials in which the parameterized recharge was increased in $5 \mathrm{~mm}_{\text {year }}{ }^{-1}$ increments, from 20 (the first point in the left in Fig. 5 and the minimum value of recharge necessary to generate the baseline $Q_{\mathrm{d}}$ of $20 \mathrm{~mm}$ year $^{-1}$ ) to $115 \mathrm{~mm}$ year $^{-1}$. With the average $\Delta \mathrm{GW}$ and $Q_{\mathrm{d}}$ (Sect. 3.1), this corresponds to a $\mathrm{GW}_{\mathrm{WD}}$ range of $60-155 \mathrm{~mm}$ year $^{-1}$. The procedure assumes only minimal differences exist in $Q_{\mathrm{d}}$ computed for the baseline and trial simulations, an assumption that we verified by inspecting irrigation simulation outputs. Since the Central Valley aquifer system is a combination of unconfined and confined aquifers, we assume that 


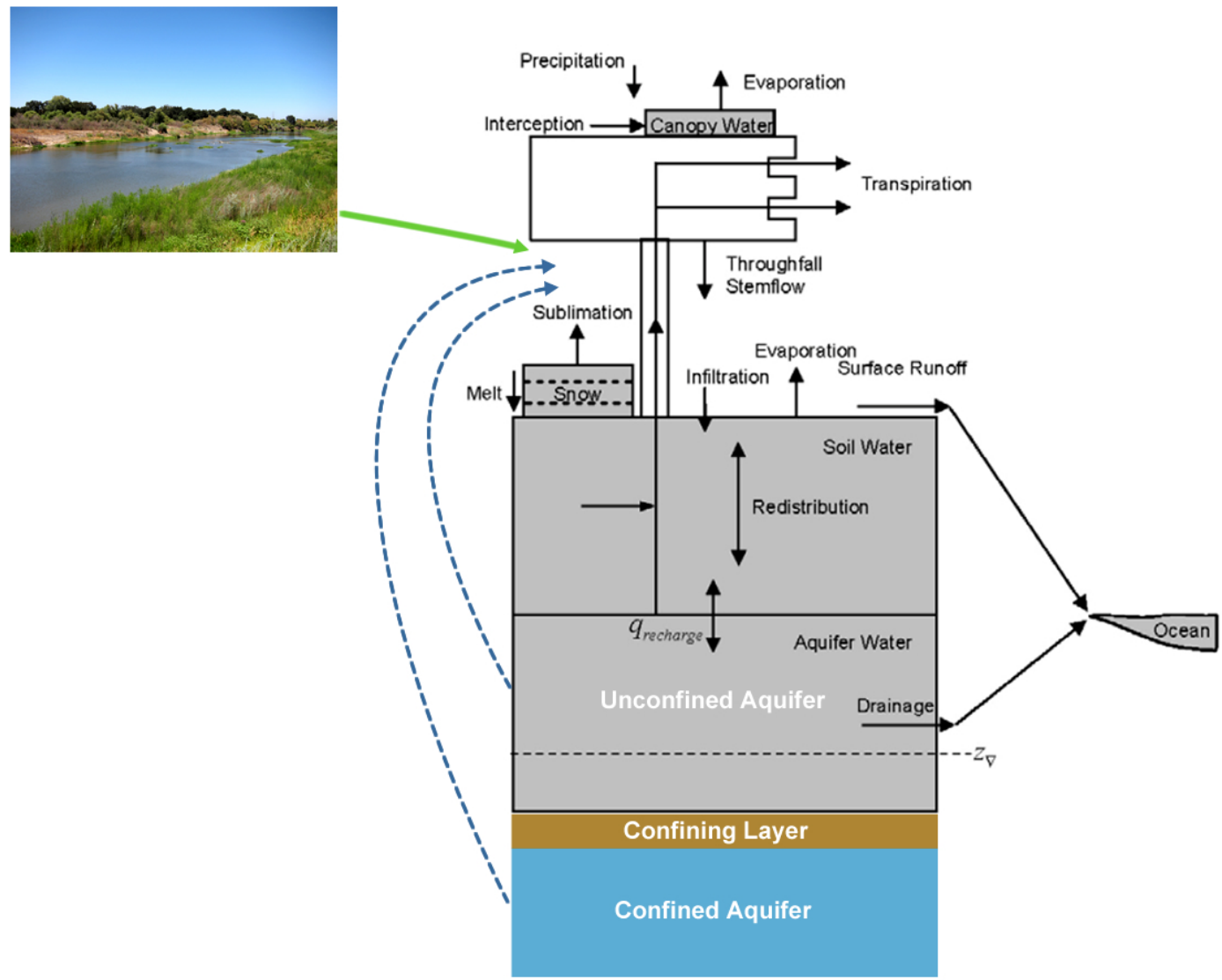

Figure 2. Conceptual schematic of land hydrological processes, modified from Oleson et al. (2008). Blue dashed and green lines indicate the irrigation water fluxes applied in the CLM. In the Central Valley, the aquifer is variably confined with some regions having no confinement.

groundwater withdrawals are equally distributed between both types of aquifers (Fig. 2). Because the CLM lacks a confined aquifer component, confined withdrawal is taken from a hypothetical water store, which is constrained together with the unconfined aquifer using Eq. (4) and GRACE-estimated groundwater. Unconfined withdrawals were taken from the saturated zone of the soil.

\section{Results and discussion}

\subsection{Existing model parameterizations and satellite-observed hydrologic fluxes}

Monthly satellite-observed and simulated ET for the Central Valley showed strong and differing seasonality (Fig. 3a). Satellite-observed monthly ET ranged from $13 \mathrm{~mm}$ month $^{-1}$ (December 2009) to $106 \mathrm{~mm}$ (July 2005). Seasonal maxima and minima of ET coincided with seasonal maxima and minima of regional solar radiation and temperatures that control potential ET (solar radiation and temperature data not shown). Over the entire 2004-2009 study period, mean $( \pm 1$ standard deviation) satellite-observed ET was $54.6 \pm 12.8 \mathrm{~mm} \mathrm{month}^{-1}\left(655 \mathrm{~mm}\right.$ year $\left.^{-1}\right)$. The GLDAS-1,
NLDAS-2, and CLM-simulated ET was substantially lower than satellite-observed ET (Fig. 3a), with a mean simulated ET of $23.3 \pm 5.0 \mathrm{~mm} \mathrm{month}^{-1}\left(280 \mathrm{~mm} \mathrm{year}^{-1}\right)$. Simulated ET ranged from $19 \mathrm{~mm}^{\text {month }}{ }^{-1}$ (September 2008) to $69 \mathrm{~mm} \mathrm{month}^{-1}$ (April 2006). GLDAS-1/NLDAS-2/CLMsimulated seasonal maxima and minima of ET coincided with maximal and minimal natural soil moisture availability following the end of the winter rainy season and at the end of the dry summer season (Fig. 3c). On an average seasonal basis, satellite-observed ET showed the greatest difference from simulated ET in July, when satellite ET was $79 \mathrm{~mm} \mathrm{month}^{-1}$ larger. In winter (NovemberFebruary), observed ET exceeded simulated ET by less than $10 \mathrm{~mm} \mathrm{month}^{-1}$ (Fig. 3c).

While the seasonality of satellite-observed and simulated ET was different, the annual patterns of ET matched annual precipitation well, although satellite-observed ET had considerably lower interannual variation than simulated ET (Fig. 3). Annual precipitation ranged from 202 (2007 calendar year) to $416 \mathrm{~mm} \mathrm{year}^{-1}$ (2005 calendar year). Mean ( \pm 1 standard deviation) calendar year precipitation for 2004-2009 was $315.8 \pm 84.8 \mathrm{~mm}$ year $^{-1}$. Annual changes in groundwater vary considerably from year to year, with 

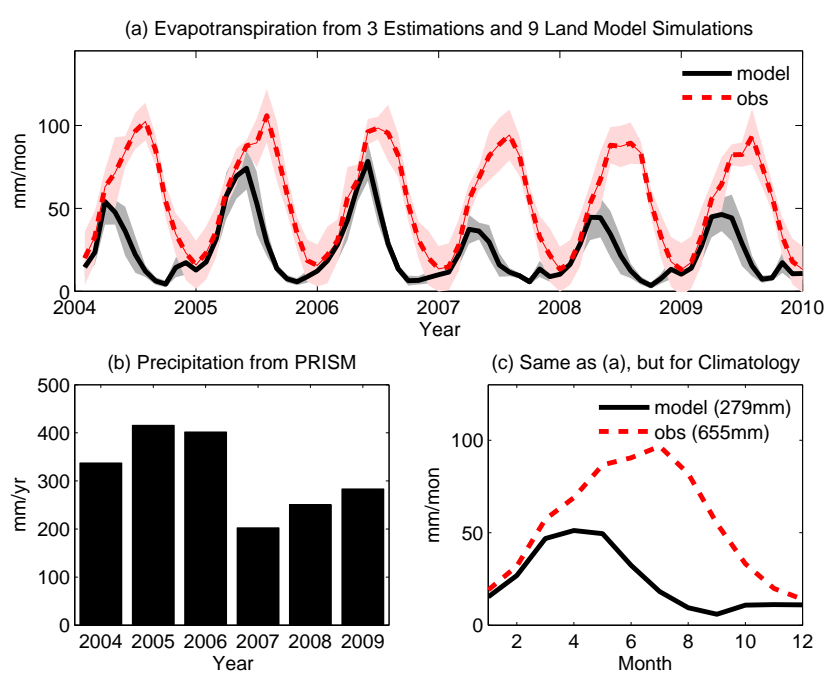

Figure 3. (a) the comparison between the remote-sensing-estimated ET, and nine GLDAS, NLDAS, and CLM models. The lines indicate the ensemble mean while the shading indicates uncertainty around the ensemble mean, (b) annual precipitation for the Central Valley, and (c) monthly climatology for satellite-observed and modeled ET.

a maximum increase of $120{\mathrm{~mm} y e a r^{-1}}^{-1} 2006$ and a maximum decrease of $220 \mathrm{~mm}^{-1} \mathrm{ear}^{-1}$ in 2007 (Fig. 4). Mean groundwater decrease across the entire study period is approximately $60 \mathrm{~mm}_{\text {year }}{ }^{-1}$. Annual precipitation and groundwater change are well correlated $(r=0.78)$, with the largest groundwater decrease occurring in one of the driest years in California history (2007) and the largest increase in 2006 following a succession of wet years. Mean annual satellite-observed ET showed less variation than precipitation, ranging from 624 in 2009 to $690 \mathrm{~mm} \mathrm{year}^{-1}$ in 2005 . Since precipitation in the surface water source regions for the Central Valley (Sierra Nevada mountains) is very well correlated with precipitation in the valley (Daly et al., 1994, 2008), variations in precipitation are also assumed to be variations in surface water availability. Together, this lower variation in ET in spite of higher variation in precipitation and surface water availability and the inverse relationship between groundwater level change and precipitation is consistent with the relatively steady water demand from Californian agricultural crops, many of which are perennial crops with large, multi-year investments (Ayars, 2013; Blank, 2000), and the long-standing practice of increasing groundwater use to compensate for deficits in surface supplies and precipitation (Howitt, 1991).

\subsection{Application of groundwater and surface water in CLM and impact on CLM-simulated ET}

The mean amount of additional water that is consumed or transpired under irrigation in the Central Valley is 376 mm year $^{-1}$ (satellite-observed ET minus the mean

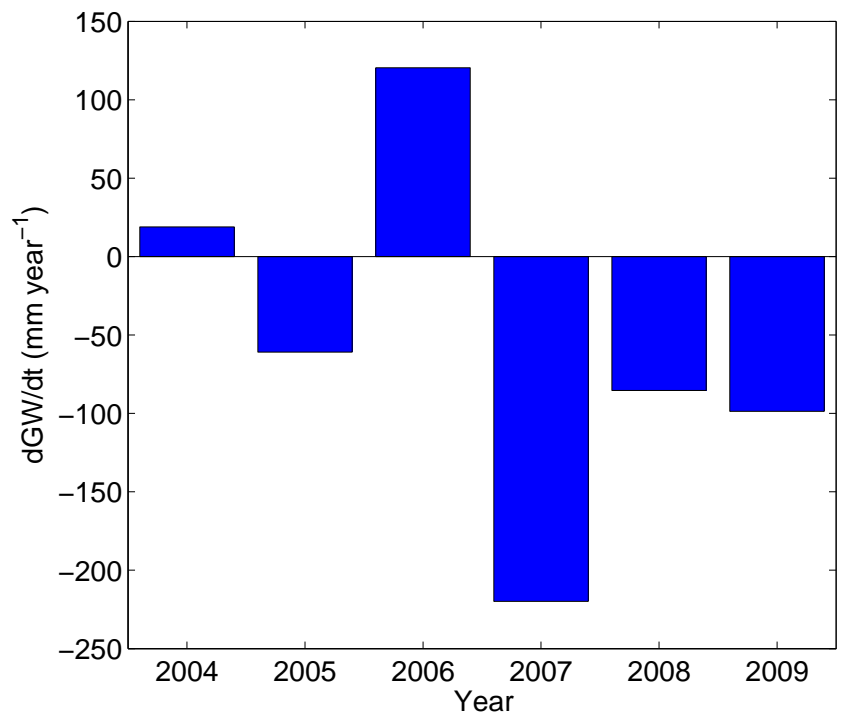

Figure 4. Annual groundwater change for the Central Valley derived from GRACE.

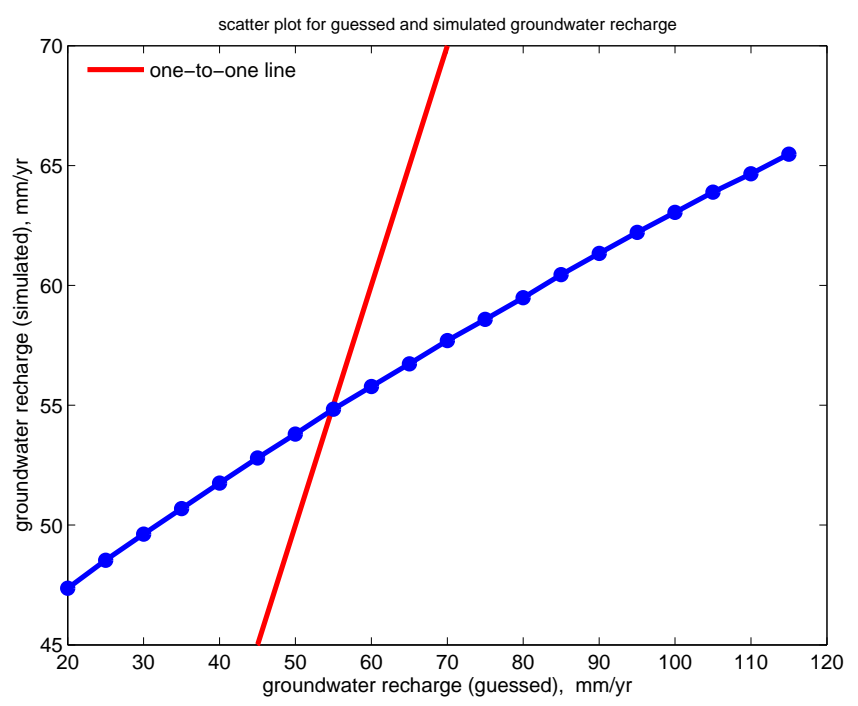

Figure 5. Parameterized (guessed) groundwater recharge versus recharge simulated in CLM 4 (see Sect. 2.3). The $x$ axis represents the trial recharge used in Eq. (4) to obtain $\mathrm{GW}_{W D}$ and the $y$ axis represents the output recharge from Eq. (3). The intersection of the parameterized values with simulated values $\left(55\right.$ mm year $\left.^{-1}\right)$ represents where recharge comes to convergence and is the value of recharge used to separate total water use into ground- and surfacewater pumping components.

GLDAS-1/NLDAS-2/CLM ensemble-simulated ET). The parameterized recharge estimates plotted against CLMsimulated recharge are shown in Fig. 5. Simulated recharge ( $\left.q_{\text {recharge }}\right)$ showed a more dampened response to a wide range of parameterized recharges, with simulated recharge ranging from 47 to $66 \mathrm{~mm} \mathrm{year}^{-1}$ across the parameterized 


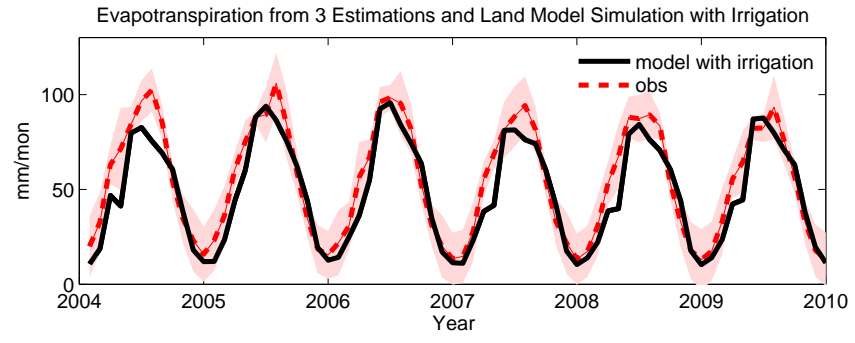

Figure 6. Monthly ET from CLM 4 with the improved irrigation parameterization when compared to observations. Lines indicate model or ensemble mean while shading indicates uncertainty of the satellite-observed ET.

recharge space $\left(20-115 \mathrm{~mm}_{\text {year }}{ }^{-1}\right)$. The parameterized and simulated recharge comes to convergence at approximately $55 \mathrm{~mm}$ year $^{-1}$ (Fig. 5), which is the value we used to partition applied surface water and groundwater. Using equation 4 , we calculated mean applied groundwater $\left(\mathrm{GW}_{\mathrm{WD}}\right)$ as $95 \mathrm{~mm}$ year $^{-1}$ over the 2004-2009 study period. Mean applied surface water $\left(\mathrm{SW}_{\mathrm{WD}}\right)$ was $281 \mathrm{~mm}$ year $^{-1}$.

The model-optimized $\mathrm{SW}_{\mathrm{WD}}$ compares well with previous remote sensing and high resolution inventory estimates of surface water consumption in the Central Valley. For the 2004-2008 water years, Anderson et al. (2012) found a mean ( \pm uncertainty) surface water consumption of $291 \pm 32 \mathrm{mmyear}^{-1}$ using remote sensing and $308 \pm 7 \mathrm{~mm}$ year $^{-1}$ using an inventory approach calculated from dam releases into the Central Valley, canal exports to coastal basins to the south, and outflow through the California Delta. The close comparison of these values to $\mathrm{SW}_{\mathrm{WD}}$ gives us further confidence in our optimization method and its underlying assumptions.

Figure 6 shows the impact of the irrigation water parameterization on CLM-simulated ET compared to observational data. With the new parameterization, monthly CLMsimulated ET ranged from a minimum of $10 \mathrm{~mm}$ (December 2008) to a maximum of $96 \mathrm{~mm}$ (June 2006), with a mean of $48.3 \mathrm{~mm}$. The differences between CLM-simulated ET and satellite-observed ET (CLM minus satellite) ranged from -30 to $11 \mathrm{~mm} \mathrm{month}^{-1}$ with a mean difference of $-6.3 \mathrm{~mm} \mathrm{month}^{-1}$. There was low correlation between seasonality (month) and the discrepancy between satelliteobserved and non-irrigated simulated ET $(r<0.5)$ as assessed with a geometric mean regression. Conversely, the relationship between satellite-observed monthly ET and CLMsimulated ET was excellent $(r=0.95$, slope $=0.94$, intercept $=-3.1 \mathrm{~mm} \mathrm{month}^{-1}$ ).

With respect to other hydrologic fluxes, simulated groundwater baseflow $\left(Q_{\mathrm{d}}\right)$ changed little with irrigation over the 2004-2009 study period (27 $\mathrm{mm}$ year $^{-1}$ in experimental run versus $18 \mathrm{~mm}$ year $^{-1}$ in control - data not shown). Surface runoff $\left(Q_{\mathrm{S}}\right)$ changed more considerably $\left(68 \mathrm{~mm} \mathrm{year}^{-1}\right.$ in experimental run versus $38 \mathrm{~mm}_{\text {year }}{ }^{-1}$ in control), which is

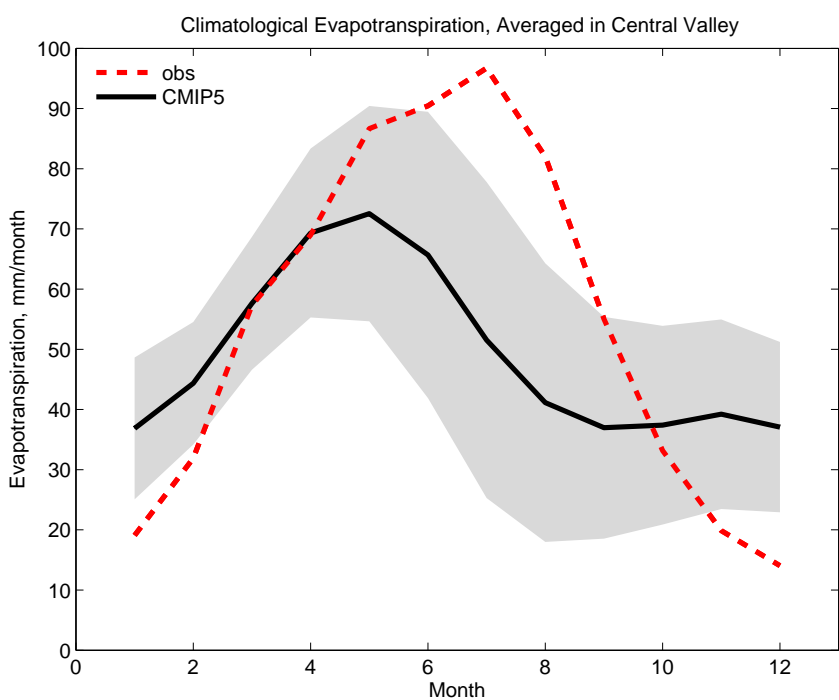

Figure 7. Mean seasonal cycle from the CMIP5 suite of models compared against satellite-observed ET. Solid line shows mean value of CMIP5 model members and shaded region shows uncertainty (2 standard deviations around mean).

an expected consequence due to the wet soil from irrigation leading to higher surface runoff. The small change in $Q_{\mathrm{d}}$ despite additional irrigation concurs with GRACE-derived groundwater changes, simulated reductions in groundwater in CLM, and previous hydrogeologic observations that many rivers and streams in the Central Valley are now losing streams due to long-term groundwater depletion, with some wells in the southern Central Valley being over $1000 \mathrm{~m}$ deep (Planert and Williams, 1995). The larger increase in $Q_{\mathrm{S}}$ may reflect on the ground spatial differences in cropping patterns and water management within the Central Valley. For example, the northern part of the Central Valley (Sacramento Valley) has extensive rice production that results in multiple flooding and drainage events in the course of a production season (Hill et al., 2006). Much of this water is reused further downstream (south). Other cropping systems, particularly those in parts of the southern Central Valley (San Joaquin Valley) affected by drainage issues, use tail water recovery systems as required by state and local regulations, which minimize surface runoff from irrigation (Schwankl et al., 2007).

\subsection{Impact of parameterizations of irrigated agriculture in land surface modeling}

The significant underestimation of peak growing season ET in irrigated agricultural regions is not confined to the NLDAS/GLDAS and default CLM models. Figure 7 shows the mean climatology of ET for the control runs of the CMIP5 models over the Central Valley compared to satelliteobserved ET. The mean ( \pm 1 standard deviation) ET is $45.9 \pm 15.8 \mathrm{~mm} \mathrm{month}^{-1}$. While the peak ET of the mean 
of the CMIP5 ensemble is higher ( 68 vs. $48 \mathrm{~mm} \mathrm{month}^{-1}$ ) and later (May vs. April) than the NLDAS/GLDAS/CLM ensemble, the CMIP5 ET still is more than $100 \mathrm{~mm} \mathrm{year}^{-1}$ lower than satellite-observed ET (550 vs. $655 \mathrm{~mm} \mathrm{year}^{-1}$ ) and exhibits minima and maxima characteristic of the natural hydrologic cycle. Furthermore, some of the improved closure between CMIP5 and satellite-observed ET compared to NLDAS/GLDAS/CLM could be due to substantially higher CMIP5-modeled ET during the winter. Despite the relatively large uncertainty of the CMIP5 models over the Central Valley, the satellite-observed ET for over half of the year is significantly outside of the CMIP5 envelope.

Compared with previous parameterizations of irrigation water in the Central Valley, our remote-sensing-based approach resulted in a lower consumed amount of water than the soil moisture-based parameterizations (Kueppers et al., 2007; Sorooshian et al., 2011) and a slightly higher amount of consumed water than a global-inventory-based approach (Siebert et al., 2010; Lo and Famiglietti, 2013). For the summer months of May-August, a high soil moisture parameterization at field capacity (Kueppers et al., 2007) resulted in an annual summer irrigation water consumption of $612 \mathrm{~mm} \mathrm{summer}^{-1}$ whereas a variable soil moisture parameterization (Sorooshian et al., 2011) resulted in a summer irrigation water consumption of $430 \mathrm{~mm} \mathrm{summer}^{-1}$. These values do not include potential water consumption from the shoulder irrigation months of April, September, and October. The inventory data of Siebert et al. (2010) used in the Lo and Famiglietti (2013) parameterization was only about $25 \mathrm{~mm}$ lower $\left(350 \mathrm{~mm}\right.$ year $^{-1}$ vs. $376 \mathrm{~mm}_{\text {year }}{ }^{-1}$ ) than our remote sensing parameterization, but the amount of consumed water from groundwater $\left(140 \mathrm{~mm}_{\text {year }}{ }^{-1}\right)$ was substantially higher than our applied groundwater $\left(95 \mathrm{~mm}\right.$ year $\left.^{-1}\right)$. Furthermore, our satellite-ET-derived estimate is also likely to be a lower envelope estimate of applied water due to the slight increase in surface runoff observed in CLM. The overestimation of ET and latent heat fluxes with the soil moisture parameterization suggests challenges in using this type of parameterization; however, soil moisture parameterization may become significantly more feasible with precise and accurate regional and global soil moisture observations from upcoming missions such as the Soil Moisture Active Passive satellite, whose outputs are specifically designed to improve inputs to numerical weather prediction and land surface models (Entekhabi et al., 2010).

Currently, both inventory and remote-sensing-based approaches have sufficiently low spatial and temporal resolution so that irrigation water parameterization is typically done on interannual timescales for large basins. This temporal resolution for water parameterization works well for accurately modeling the hydrology of the Central Valley, likely due to the lower amount of interannual variation in ET and the use of groundwater to compensate for surface water deficits. However, it is unclear how well this approach will work in irrigated regions where ET may be more variable due to a lack of supplemental reservoirs and thus a necessary fallowing of land during dry periods. Current and future missions (GPM, SMAP, SWOT, GRACE Follow-On/GRACE II) have the potential to sufficiently improve the resolution of satellite hydrologic products to enable annual quantification of surface water and groundwater application at higher spatial resolution (Biancamaria et al., 2010; Entekhabi et al., 2010; Smith et al., 2007; Zheng et al., 2015). These higher resolution parameterizations may enable better quantification of hydrologic impacts of changing management and cropping patterns, including shifts in irrigation regimes and changes between annual and perennial crops. Parameterizations from inventory methods may improve if public monitoring and reports requirements become more widespread (similar to those for Arizona's Active Management Areas see Jacobs and Holway, 2004).

\section{Summary and conclusion}

We used satellite-based estimates of evapotranspiration (ET) and groundwater change combined with precipitation data to constrain and parameterize the additional water applied to a major irrigated agricultural region (Central Valley, California, USA) for simulation of land surface fluxes using the Community Land Model (CLM) version 4 . We evaluated the baseline amount of consumed water using a suite of nine land surface models/forcing data sets and estimating the additional water consumed as a residual of current satellite observations. We used an iterative solution of parameterizing and then simulating groundwater recharge to partition the total water withdrawals among ground and surface water. The additional water parameterization resulted in CLM tracking the total amount and seasonality of ET closely. The remote sensing parameterization of irrigation water consumption results in a smaller total amount of water being consumed than in previous soil-moisture-based parameterizations.

The results emphasize the need for irrigation parameterization in land and climate models to accurately assess landatmosphere energy and mass fluxes in regions with major anthropogenic modifications. Given the potential for intense irrigation to modify regional climate (Kueppers et al., 2007) and to enhance convection precipitation in downwind regions (Lo and Famiglietti, 2013), it is important that the additional water consumption from irrigation is properly represented to better model the local and more distant impacts of anthropogenic land surface modification. Particular emphasis should be placed on evaluating irrigation impacts in lessdeveloped regions with fewer surface data constraints and different cultivation and irrigation practices than the Central Valley. An improved parameterization will also be useful for assessing regional climatic impacts of possible future changes in irrigated agricultural regions due to increased logistical, political, and/or economic restrictions on groundwater pumping or changes in surface water use. 


\section{The Supplement related to this article is available online at doi:10.5194/gmd-8-3021-2015-supplement.}

Acknowledgements. The GLDAS and NLDAS data used in this study were acquired as part of the mission of NASA's Earth Science Division and archived and distributed by the Goddard Earth Sciences (GES) Data and Information Services Center (DISC). A portion of this research was conducted at the Jet Propulsion Laboratory, California Institute of Technology, operated under contract with NASA. This study was supported by the Ministry of Science and Technology, Taiwan, (grants MOST 103-2111-M002-006 and MOST 100-2119-M-001-029-MY5), by the United States Department of Agriculture, Agricultural Research Service ${ }^{1}$, National Program 211: Water Availability and Watershed Management (project no. 2036-61000-015-00), and by the University of California Multicampus Research Programs and Initiatives (MRPI).

Edited by: W. Hazeleger

\section{References}

Allen, R. G., Tasumi, M., and Trezza, R.: Satellite-Based Energy Balance for Mapping Evapotranspiration with Internalized Calibration (METRIC) - Model, J. Irrig. Drain. Eng., 133, 380-394, 2007.

Anderson, M. C., Norman, J. M., Mecikalski, J. R., Otkin, J. A., and Kustas, W. P.: A climatological study of evapotranspiration and moisture stress across the continental United States based on thermal remote sensing: 1. Model formulation, J. Geophys. Res., 112, D10117, doi:10.1029/2006JD007506, 2007.

Anderson, R. G., Lo, M.-H., and Famiglietti, J. S.: Assessing surface water consumption using remotely-sensed groundwater, evapotranspiration, and precipitation, Geophys. Res. Lett., 39, L16401, doi:10.1029/2012GL052400, 2012.

Ayars, J. E.: Adapting Irrigated Agriculture to Drought in the San Joaquin Valley of California, in Drought in Arid and Semi-Arid Regions, edited by: Schwabe, K., Albiac, J., Connor, J. D., Hassan, R. M., and Meza González, L., 25-39, Springer Netherlands, Dordrecht, 2013.

\footnotetext{
${ }^{1}$ Note: The US Department of Agriculture (USDA) prohibits discrimination in all its programs and activities on the basis of race, color, national origin, age, disability, and where applicable, sex, marital status, familial status, parental status, religion, sexual orientation, genetic information, political beliefs, reprisal, or because all or part of an individual's income is derived from any public assistance program. (Not all prohibited bases apply to all programs.) Persons with disabilities who require alternative means for communication of program information (Braille, large print, audiotape, etc.) should contact USDA's TARGET Center at (202) 720-2600 (voice and TDD). To file a complaint of discrimination, write to USDA, Director, Office of Civil Rights, 1400 Independence Avenue, S.W., Washington, DC 20250-9410, or call (800) 795-3272 (voice) or (202) 720-6382 (TDD). USDA is an equal opportunity provider and employer.
}

Bastiaanssen, W. G. M., Menenti, M., Feddes, R. A., and Holtslag, A. A. M.: A remote sensing surface energy balance algorithm for land (SEBAL), 1. Formulation, J. Hydrol., 212/213, 198-212, 1998.

Biancamaria, S., Andreadis, K. M., Durand, M., Clark, E. A., Rodriguez, E., Mognard, N. M., Alsdorf, D. E., Lettenmaier, D. P., and Oudin, Y.: Preliminary Characterization of SWOT Hydrology Error Budget and Global Capabilities, IEEE J. Sel. Top. Appl., 3, 6-19, 2010.

Blank, S. C.: Perspective: Is this California agriculture's last century?, California Agric., 54, 23-25, 2000.

Borsa, A. A., Agnew, D. C. and Cayan, D. R.: Ongoing droughtinduced uplift in the western United States, Science, 345, 15871590, 2014.

California Department of Food and Agriculture: California Agricultural Statistics Review 2013-2014, available from: http:// www.cdfa.ca.gov/statistics/pdfs/2013/AgStatsOverview.pdf (last access: 12 December 2014), 2014.

Canessa, P., Green, S., and Zoldoske, D: Agricultural Water Use in California: A 2011 Update, Center for Irrigation Technology, California State University, Fresno, available from: http://www. californiawater.org/cwi/docs/CIT_AWU_REPORT_v2.pdf (last access: 17 July 2015), 2011.

Chung, I. and Helweg, O.: Modeling the California State Water Project, J. Water Resour. Plann. Manage., 111, 82-97, 1985.

Cuenca, R., Ciotti, S., and Hagimoto, Y.: Application of Landsat to Evaluate Effects of Irrigation Forbearance, Remote Sens., 5, 3776-3802, 2013.

Daly, C., Neilson, R. P., and Phillips, D. L.: A StatisticalTopographic Model for Mapping Climatological Precipitation over Mountainous Terrain, J. Appl. Meteor., 33, 140-158, 1994.

Daly, C., Halbleib, M., Smith, J. I., Gibson, W. P., Doggett, M. K., Taylor, G. H., Curtis, J., and Pasteris, P. P.: Physiographically sensitive mapping of climatological temperature and precipitation across the conterminous United States, Int. J. Climatol., 28, 2031-2064, 2008.

Entekhabi, D., Njoku, E. G., O’Neill, P. E., Kellogg, K. H., Crow, W. T., Edelstein, W. N., Entin, J. K., Goodman, S. D., Jackson, T. J., Johnson, J., Kimball, J., Piepmeier, J. R., Koster, R. D., Martin, N., McDonald, K. C., Moghaddam, M., Moran, S., Reichle, R., Shi, J. C., Spencer, M. W., Thurman, S. W., Tsang, L., and Van Zyl, J.: The Soil Moisture Active Passive (SMAP) Mission, Proc. IEEE, 98, 704-716, 2010.

Famiglietti, J. S.: The global groundwater crisis, Nature Clim. Change, 4, 945-948, 2014.

Famiglietti, J. S., Lo, M., Ho, S. L., Bethune, J., Anderson, K. J., Syed, T. H., Swenson, S. C., de Linage, C. R., and Rodell, M.: Satellites measure recent rates of groundwater depletion in California's Central Valley, Geophys. Res. Lett., 38, L03403, doi:10.1029/2010GL046442, 2011.

Faunt, C., Ed.: Groundwater availability of the Central Valley Aquifer, California, US Geological Survey, Reston, Va., available at: http://pubs.usgs.gov/pp/1766/PP_1766.pdf, 2009.

Ferguson, I. M. and Maxwell, R. M.: Human impacts on terrestrial hydrology: climate change versus pumping and irrigation, Environ. Res. Lett., 7, 044022, doi:10.1088/1748-9326/7/4/044022, 2012.

Fischhendler, I. and Zilberman, D.: Packaging policies to reform the water sector: The case of the Central Valley 
Project Improvement Act, Water Resources Res., 41, W07024, doi:10.1029/2004WR003786, 2005.

Haddeland, I., Lettenmaier, D. P., and Skaugen, T.: Effects of irrigation on the water and energy balances of the Colorado and Mekong river basins, J. Hydrol., 324, 210-223, 2006.

Hart, Q. J., Brugnach, M., Temesgen, B., Rueda, C., Ustin, S. L., and Frame, K.: Daily reference evapotranspiration for California using satellite imagery and weather station measurement interpolation, Civil Eng. Environ. Sys., 26, 19-33, 2009.

Harter, T. and Dahlke, H. E.: Out of sight but not out of mind: California refocuses on groundwater, California Agric., 68, 54-55, 2014.

Hill, J. E., Williams, J. F., Mutters, R. G., and Greer, C. A.: The California rice cropping system: agronomic and natural resource issues for long-term sustainability, Paddy Water Environ., 4, 13 19, 2006.

Howitt, R.: When water is scarce: Ground water is key to easing impact of drought, California Agric., 45, 4-9, 1991.

Jacobs, K. L. and Holway, J. M.: Managing for sustainability in an arid climate: lessons learned from 20 years of groundwater management in Arizona, USA, Hydrogeol. J., 12, 52-65, 2004.

Jin, Y., Randerson, J. T., and Goulden, M. L.: Continental-scale net radiation and evapotranspiration estimated using MODIS satellite observations, Remote Sens. Environ., 115, 2302-2319, 2011.

Jung, M., Reichstein, M., Ciais, P., Seneviratne, S. I., Sheffield, J., Goulden, M. L., Bonan, G., Cescatti, A., Chen, J., de Jeu, R., Dolman, A. J., Eugster, W., Gerten, D., Gianelle, D., Gobron, N., Heinke, J., Kimball, J., Law, B. E., Montagnani, L., Mu, Q., Mueller, B., Oleson, K., Papale, D., Richardson, A. D., Roupsard, O., Running, S., Tomelleri, E., Viovy, N., Weber, U., Williams, C., Wood, E., Zaehle, S., and Zhang, K.: Recent decline in the global land evapotranspiration trend due to limited moisture supply, Nature, 467, 951-954, 2010.

Kueppers, L. M., Snyder, M. A., and Sloan, L. C.: Irrigation cooling effect: Regional climate forcing by land-use change, Geophys. Res. Lett., 34, L03703, doi:10.1029/2006GL028679, 2007.

Lawrence, D. M., Oleson, K. W., Flanner, M. G., Thornton, P. E., Swenson, S. C., Lawrence, P. J., Zeng, X., Yang, Z.-L., Levis, S., Sakaguchi, K., Bonan, G. B., and Slater, A. G.: Parameterization improvements and functional and structural advances in Version 4 of the Community Land Model, J. Adv. Model. Earth Syst., 3, M03001, doi:10.1029/2011MS000045, 2011.

Lei, H., Yang, D., Yang, H., Yuan, Z., and Lv, H.: Simulated impacts of irrigation on evapotranspiration in a strongly exploited region: a case study of the Haihe River basin, China, Hydrol. Proc., 29, 2704-2719, 2015.

Leng, G., Huang, M., Tang, Q., Sacks, W. J., Lei, H., and Leung, L. R.: Modeling the effects of irrigation on land surface fluxes and states over the conterminous United States: Sensitivity to input data and model parameters, J. Geophys. Res. Atmos., 118, 9789 9803, 2013.

Leng, G., Huang, M., Tang, Q., Gao, H., and Leung, L. R.: Modeling the Effects of Groundwater-Fed Irrigation on Terrestrial Hydrology over the Conterminous United States, J. Hydrometeorol., 15, 957-972, 2014.

Lo, M.-H. and Famiglietti, J. S.: Irrigation in California's Central Valley strengthens the southwestern U.S. water cycle, Geophys. Res. Lett., 40, 301-306, 2013.
Lo, M.-H., Wu, C.-M., Ma, H.-Y., and Famiglietti, J. S.: The response of coastal stratocumulus clouds to agricultural irrigation in California, J. Geophys. Res. Atmos., 118, 6044-6051, 2013.

Lobell, D., Bala, G., Mirin, A., Phillips, T., Maxwell, R., and Rotman, D.: Regional Differences in the Influence of Irrigation on Climate, J. Clim., 22, 2248-2255, 2009.

Miralles, D. G., Holmes, T. R. H., De Jeu, R. A. M., Gash, J. H., Meesters, A. G. C. A., and Dolman, A. J.: Global landsurface evaporation estimated from satellite-based observations, Hydrol. Earth Sys. Sci., 15, 453-469, doi:10.5194/hess-15-4532011, 2011.

Mitchell, K. E.: The multi-institution North American Land Data Assimilation System (NLDAS): Utilizing multiple GCIP products and partners in a continental distributed hydrological modeling system, J. Geophys. Res., 109, G01021, doi:10.1029/2003JD003823, 2004.

Mu, Q., Zhao, M., and Running, S. W.: Improvements to a MODIS global terrestrial evapotranspiration algorithm, Remote Sens. Environ., 115, 1781-1800, 2011.

Oleson, K. W., Niu, G.-Y., Yang, Z.-L., Lawrence, D. M., Thornton, P. E., Lawrence, P. J., Stöckli, R., Dickinson, R. E., Bonan, G. B., Levis, S., Dai, A., and Qian, T.: Improvements to the Community Land Model and their impact on the hydrological cycle, J. Geophys. Res., 113, G01021, doi:10.1029/2007JG000563, 2008.

Ozdogan, M., Rodell, M., Beaudoing, H. K., and Toll, D. L.: Simulating the Effects of Irrigation over the United States in a Land Surface Model Based on Satellite-Derived Agricultural Data, J. Hydrometeorol., 11, 171-184, 2010.

Planert, M. and Williams, J. S.: Ground water atlas of the United States: Segment 1, California, Nevada, 1995.

Postel, S. L., Daily, G. C., and Ehrlich, P. R.: Human Appropriation of Renewable Fresh Water, Science, 271, 785-788, 1996.

Priestley, C. H. B. and Taylor, R. J.: On the Assessment of Surface Heat Flux and Evaporation Using Large-Scale Parameters, Mon. Wea. Rev., 100, 81-92, 1972.

Rodell, M., Houser, P. R., Jambor, U., Gottschalck, J., Mitchell, K., Meng, C.-J., Arsenault, K., Cosgrove, B., Radakovich, J., Bosilovich, M., Entin*, J. K., Walker, J. P., Lohmann, D., and Toll, D.: The Global Land Data Assimilation System, Bul. Am. Meteorol. Soc., 85, 381-394, 2004.

Rodell, M., Velicogna, I., and Famiglietti, J. S.: Satellite-based estimates of groundwater depletion in India, Nature, 460, 999-1002, 2009.

Scanlon, B. R., Faunt, C. C., Longuevergne, L., Reedy, R. C., Alley, W. M., McGuire, V. L., and McMahon, P. B.: Groundwater depletion and sustainability of irrigation in the US High Plains and Central Valley, Proc. Nat. Acad. Sci., 109, 9320-9325, 2012.

Schwankl, L. J., Prichard, T. L., and Hanson, B. R.: Tailwater Return Systems, University of California, available from: http: //anrcatalog.ucdavis.edu/pdf/8225.pdf (last access: 6 December 2014), 2007.

Siebert, S., Burke, J., Faures, J. M., Frenken, K., Hoogeveen, J., Döll, P., and Portmann, F. T.: Groundwater use for irrigation - a global inventory, Hydrol. Earth Sys. Sci., 14, 1863-1880, doi:10.5194/hess-14-1863-2010, 2010.

Smith, E. A., Asrar, G., Furuhama, Y., Ginati, A., Mugnai, A., Nakamura, K., Adler, R. F., Chou, M.-D., Desbois, M., Durning, J. F., Entin, J. K., Einaudi, F., Ferraro, R. R., Guzzi, R., Houser, P. R., Hwang, P. H., Iguchi, T., Joe, P., Kakar, R., Kaye, J. A., Kojima, 
M., Kummerow, C., Kuo, K.-S., Lettenmaier, D. P., Levizzani, V., Lu, N., Mehta, A. V., Morales, C., Morel, P., Nakazawa, T., Neeck, S. P., Okamoto, K., Oki, R., Raju, G., Shepherd, J. M., Simpson, J., Sohn, B.-J., Stocker, E. F., Tao, W.-K., Testud, J., Tripoli, G. J., Wood, E. F., Yang, S., and Zhang, W.: International Global Precipitation Measurement (GPM) Program and Mission: An Overview, in Measuring Precipitation From Space, edited by: Levizzani, V., Bauer, P., and Turk, F. J., Springer Netherlands, Dordrecht, 611-653, 2007.

Sorooshian, S., Li, J., Hsu, K., and Gao, X.: How significant is the impact of irrigation on the local hydroclimate in California's Central Valley? Comparison of model results with ground and remote-sensing data, J. Geophys. Res., 116, D06102, doi:10.1029/2010JD014775, 2011.

Steele, D. D., Thoreson, B. P., Hopkins, D. G., Clark, B. A., Tuscherer, S. R., and Gautam, R.: Spatial mapping of evapotranspiration over Devils Lake basin with SEBAL: application to flood mitigation via irrigation of agricultural crops, Irrigation Sci., 33, 15-29, 2015.

Swenson, S. and Wahr, J.: Monitoring Changes in Continental Water Storage with GRACE, Space Sci. Rev., 108, 345-354, 2003.

Tang, Q., Oki, T., Kanae, S., and Hu, H.: The Influence of Precipitation Variability and Partial Irrigation within Grid Cells on a Hydrological Simulation, J. Hydrometeorol., 8, 499-512, 2007.

Tang, Q., Oki, T., Kanae, S., and Hu, H.: Hydrological Cycles Change in the Yellow River Basin during the Last Half of the Twentieth Century, J. Clim., 21, 1790-1806, 2008.

Tang, Q., Peterson, S., Cuenca, R. H., Hagimoto, Y., and Lettenmaier, D. P.: Satellite-based near-real-time estimation of irrigated crop water consumption, J. Geophys. Res., 114, D05114, doi:10.1029/2008JD010854, 2009a.

Tang, Q., Rosenberg, E. A., and Lettenmaier, D. P.: Use of satellite data to assess the impacts of irrigation withdrawals on Upper Klamath Lake, Oregon, Hydrol. Earth Sys. Sci., 13, 617-627, doi:10.5194/hess-13-617-2009, 2009 b.

Tapley, B. D., Bettadpur, S., Watkins, M., and Reigber, C.: The gravity recovery and climate experiment: Mission overview and early results, Geophys. Res. Lett., 31, L09607, doi:10.1029/2004GL019920, 2004.

Taylor, K. E., Stouffer, R. J., and Meehl, G. A.: An Overview of CMIP5 and the Experiment Design, Bul. Am. Meteorol. Soc., 93, 485-498, 2012.

USDA National Agricultural Statistics Service: 2012 Census of Agriculture, California State and County Data, available from: http://www.agcensus.usda.gov/Publications/2012/Full_Report/ Volume_1,_Chapter_2_County_Level/California/cav1.pdf (last access: 17 July 2015), 2014.
Van Dijk, A. I. J. M., Renzullo, L. J., Wada, Y., and Tregoning, P.: A global water cycle reanalysis (2003-2012) merging satellite gravimetry and altimetry observations with a hydrological multi-model ensemble, Hydrol. Earth Sys. Sci., 18, 2955-2973, doi:10.5194/hess-18-2955-2014, 2014.

Voss, K. A., Famiglietti, J. S., Lo, M., de Linage, C., Rodell, M., and Swenson, S. C.: Groundwater depletion in the Middle East from GRACE with implications for transboundary water management in the Tigris-Euphrates-Western Iran region, Water Resour. Res., 49, 904-914, 2013.

Wada, Y., van Beek, L. P. H., van Kempen, C. M., Reckman, J. W. T. M., Vasak, S., and Bierkens, M. F. P.: Global depletion of groundwater resources, Geophys. Res. Lett., 37, L20402, doi:10.1029/2010GL044571, 2010.

Wisser, D., Frolking, S., Douglas, E. M., Fekete, B. M., Vörösmarty, C. J., and Schumann, A. H.: Global irrigation water demand: Variability and uncertainties arising from agricultural and climate data sets, Geophys. Res. Lett., 35, L24408, doi:10.1029/2008GL035296, 2008.

Xia, Y., Mitchell, K., Ek, M., Cosgrove, B., Sheffield, J., Luo, L., Alonge, C., Wei, H., Meng, J., Livneh, B., Duan, Q., and Lohmann, D.: Continental-scale water and energy flux analysis and validation for North American Land Data Assimilation System project phase 2 (NLDAS-2): 2. Validation of model-simulated streamflow, J. Geophys. Res., 117, D03110, doi:10.1029/2011JD016051, 2012a.

Xia, Y., Mitchell, K., Ek, M., Sheffield, J., Cosgrove, B., Wood, E., Luo, L., Alonge, C., Wei, H., Meng, J., Livneh, B., Lettenmaier, D., Koren, V., Duan, Q., Mo, K., Fan, Y., and Mocko, D.: Continental-scale water and energy flux analysis and validation for the North American Land Data Assimilation System project phase 2 (NLDAS-2): 1. Intercomparison and application of model products, J. Geophys. Res., 117, D03109, doi:10.1029/2011JD016048, 2012b.

Zheng, W., Hsu, H., Zhong, M., and Yun, M.: Requirements Analysis for Future Satellite Gravity Mission Improved-GRACE, Surveys Geophys., 36, 87-109, 2015.

Zhong, S., Whiteman, C. D., and Bian, X.: Diurnal Evolution of Three-Dimensional Wind and Temperature Structure in California's Central Valley, J. Appl. Meteorol., 43, 1679-1699, 2004. 